\title{
METODE DAN MANFAAT EVALUASI PENDIDIKAN ISLAM
}

\author{
${ }^{\mathbf{1}}$ Nurmi Hastuti. \\ ${ }^{1}$ Institut Agama Islam Muhammadiyah Sinjai \\ nurmihastuti10@gmail.com
}

\begin{abstract}
Abstrak
Dalam proses pendidikan Islam, metode adalah suatu cara yang tepat dan cepat dalam suatu cara yang effekif dan efisien. Pengajaran yang efektif yaitu pengajaran yang dapat dipahami murid secara sempurna. Pengajaran yang tepat ialah pengajaran yang berfungsi pada murid. Dan inilah yang dibutuhkan oleh seorang tenaga pendidik agar dapat menerapkannya guna mencapai tujuan pembelajaran.

Fungsi pendidikan Islam yaitu untuk memelihara dan mengembangkan fitrah dan sumber daya insani yang ada pada subjek didik menuju terbentuknya manusia seutuhnya sesuai denga norma Islam. Dan untuk mengetahui apakah fungsi pendidikan Islam tersebut tercapai atau tidak perlu di adakan evaluasi.
\end{abstract}




\section{BAB I \\ PENDAHULUAN}

\section{A. Latar Belakang}

Dalam proses pendidikan Islam, metode adalah suatu cara yang tepat dan cepat dalam suatu cara yang effekif dan efisien. Pengajaran yang efektif yaitu pengajaran yang dapat dipahami murid secara sempurna. Pengajaran yang tepat ialah pengajaran yang berfungsi pada murid. Dan inilah yang dibutuhkan oleh seorang tenaga pendidik agar dapat menerapkannya guna mencapai tujuan pembelajaran.

Fungsi pendidikan Islam yaitu untuk memelihara dan mengembangkan fitrah dan sumber daya insani yang ada pada subjek didik menuju terbentuknya manusia seutuhnya sesuai denga norma Islam. Dan untuk mengetahui apakah fungsi pendidikan Islam tersebut tercapai atau tidak perlu di adakan evaluasi.

Pada makalah ini akan dibahas tentang metode dan manfaat evaluasi dalam pendidikan.

\section{B. Rumusan Masalah}

1. Apa Pengertian Metode?

2. Bagaimana Metode Dalam Pendidikan Islam?

3. Apa Manfaat Evaluasi Dalam Pendidikan Islam?

\section{Tujuan Penulisan}

1. Untuk Mengetahui Pengertian Metode

2. Untuk Mengetahui Metode Dalam Pendidikan Islam

3. Untuk Mengetahui Manfaat Evaluasi Dalam Pendidikan Islam 


\section{BAB II \\ PEMBAHASAN}

\section{A. Pengertian Metode}

Metode berasal dari bahasa Yunani yang terdiri dari dua kata yaitu meta yang artinya melalui dan hodos yang artinya jalan atau cara. Jadi metode artinya suatu jalan yang dilalui untuk mencapai suatu tujuan. Menurut Ahmad Tafsir metode ialah istilah yang digunakan untuk mengungkapkan pengertian "cara yang paling tepat dan cepat dalam melakukan sesuatu". 1

Dalam bahasa Arab metode disebut dengan thariqah yaitu mengajar yang berarti menyajikan bahan pengajaran agar tercapai tujuan pengajaran. ${ }^{2}$

Sedangkan menurut KBBI, metode adalah cara teratur yang digunakan untuk melaksanakan suatu pekerjaan agar tercapai sesuatu dengan yang dikehendaki. Atau cara kerja yang bersistem untuk memudahkan pelaksanaan suatu kegiatan guna mencapai tujuan yang ditentukan. ${ }^{3}$

Dari pengertian diatas dapat ditarik kesimpulan bahwa, metode adalah suatu cara yang tepat dan cepat dalam suatu cara yang efektif dan efisien untuk mencapai tujuan yang ditentukan.

Selanjutnya metode pendidikan Islam adalah jalan atau cara yang ditempuh untuk menyampaikan bahan atau materi pendidikan islam kepada anak didik agar terwujud kepribadian muslim. ${ }^{4}$

Guru harus berinovasi agar proses belajar mengajar yang dilakukan dapat mencapai tujuan yang telah ditetapkan dalam rencana pembelajaran. ${ }^{5}$

\footnotetext{
${ }^{1}$ Haryanti, Ilmu Pendidikan Islam, (Malang: Penerbit Gunung Samudera, 2014) h. 97-98.

${ }^{2}$ Halid Hanafi, dkk., Ilmu Pendidikan Islam, (Yogyakarta: CV Budi Utama, 2018) h. 168.

${ }^{3}$ David Moeljadi, dkk., Kamus Besar Bahasa Indonesia Edisi Kelima, (Jakarta: Badan Pengembangan Bahasa Dan Perbukuan, 2016).

${ }^{4}$ Haryanti, Ilmu Pendidikan Islam, (Malang: Penerbit Gunung Samudera, 2014), h. 98.

${ }^{5}$ Anggraini, D., Arbaini, W., \& Arsil, A. (2020). Model Pembelajaran Remi (Rajin,

Efektif, Menyenangkan Dan Imajinatif) Dalam Meningkatkan Kemampuan Berfikir Kritis Siswa. Jurnal Al-Qalam: Jurnal Kajian Islam \& Pendidikan, 12(2), 14-27.
} 


\section{B. Metode Dalam Pendidikan Islam}

Banyak sekali metode yang dapat digunakan dalam penddidikan islam, asalkan dalam penerapan metode yang digunakan tersebut, tidak bertentangan dengan prinsip-prinsip ajaran Islam serta disesuaikan dengan materi pembelajaran pendidikan Islam yang sedang diberikan kepada peserta didik. guru juga harus mampu membangkitkan minat belajar bagi peserta didiknya ${ }^{6}$

Metode-metode yang dapat diterapkan dalam pendidikan islam cukup banyak diantaranya: ${ }^{7}$

1. Metode ceramah

Metode ceramah adalah suatu metode yang dilakukan oleh guru dalam menyampaikan bahan pelajaran secara lisan. Dalam metode ini yang memiliki peran aktif adalah guru.

2. Metode diskusi

Secara umum diskusi adalah suatu proses yang melibatkan dua individu atau lebih, berinteraksi secara verbal, dan saling tukar informasi, saling mempertahankan pendapat, dalam memecahkan suatu persoalan tertentu. Sedangkan metode diskusi adalah sebuah cara yang dilakukan dalam mempelajari bahan dan menyampaikan materi dengan jalan mendiskusikannya, dengan tujuan dapat menimbulkan pengertian serta perubahan tingkah laku pada siswa, atau dalam pengertian lain metode diskusi adalah suatu cara penyajian atau penyampaian bahan pelajaran dimana guru memberi kesempatan pada para siswa/kelompok siswa untuk mengadakan pembicaraan ilmiah guna mengumpulkan pendapat, membuat kesimpulan atau menyusun berbagai alternative pemecahan.

3. Metode tanya jawab

${ }^{6}$ Irmayanti, I., \& Danial, D. (2019). Eksplorasi Etnomatematika Permainan Pada Siswa Sekolah Dasar Di Sinjai Selatan. Auladuna: Jurnal Pendidikan Dasar Islam, 6(1), 90-104.

${ }^{7}$ Suriyati, dkk., Ilmu Pendidikan Islam, (Sulawesi Selatan: CV Latinulu, 2019), h. 43-46. 
Yaitu suatu cara mengajar dimana guru memberikan beberapa pertanyaan kepada murid tentang bahan pelajaran yang telah diajarkan atau bacaan yang mereka baca.

4. Metode pemberian tugas

Yaitu suatu cara mengajar dimana seorang guru memberikan tugastugas tertentu kepada murid-murid, sedangkan hasil tersebut diperiksa oleh guru dan murid harus mempertanggung jawabkannya.

5. Metode demontrasi

Yaitu suatu cara mengajar dimana guru mempertunjukkan proses sesuatu, atau pelaksanaan sesuatu sedangkan murid memperhatikannya.

6. Metode eksperimen

Yaitu suatu cara mengajar dengan menyuruh murid melakukan suatu percobaan, dan setiap proses dan hasil percobaan itu diamati oleh setiap murid, sedangkan guru memperhentikan yang dilakukan oleh murid sambil memberikan arahan.

7. Metode amsal/perumpamaan

Yaitu cara mengajar dimana guru menyampaikan materi pembelajaran melalui contoh atau perumpamaan.

8. Metode targhib dan tarhib

Yaitu cara mengajar dimana guru memberikan materi pembelajaran dengan menggunakan ganjaran terhadap kebaikan dan hukum terhadap keburukan agar peserta didik melakukan kebaikan dan menjauhi keburukan.

9. Metode pengulangan

Yaitu cara mengajar dimana guru memberikan materi ajar dengan cara mengulang-ulang materi tersebut dengan harapan siswa lebih bisa mengingat lebih lama materi yang disampaikan.

\section{Manfaat Evaluasi Dalam Pendidikan Islam}

Para pakar pendidikan Islam mendefinisikan evaluasi pendidikan islam antara lain: pertama, evaluasi pendidikan Islam adalah suatu kegiatan untuk 
menentukan taraf kemajuan suatu aktifitas di dalam pendidikan Islam. Kedua, evaluasi dalam pendidikan islam merupakan cara atau tekhnik penilaian terhadap tingkah laku peserta didik berdasarkan standar perhitungan. ${ }^{8}$

Menurut Ramayulis tujuan evaluasi pendidikan adalah untuk: ${ }^{9}$

1. Mendeskripsikan kecakapan belajar para siswa,

2. Mengetahui keberhasilan proses pendidikan dan pengajaran di sekolah,

3. Memberikan pertanggung jawaban dari pihak sekolahkepada pihak-pihak yang berkepentingan, dan

4. Menentukan tindak lanjut hasil penelitian.

Secara umum ada empat kegunaan evaluasi dalam pendidikan Islam, yaitu: ${ }^{10}$

1. Dari segi pendidik, yaitu untuk membatu seorang pendidik mengetahui sejauh mana hasil yang dicapai dalam pelaksanaan tugasnya.

2. Dari segi peserta didik, yaitu membantu peserta didik untuk dapat mengubah atau mengembangkan tingkah lakunya secara sadar ke arah yang lebih baik.

3. Dari segi ahli fikir pendidikan islam, untuk membatu para pemikir pendidikan Islam mengetahui kelemahan teori-teori pendidikan Islam dan membantu mereka merumuskan kembali teori-teori pendidikan Islam yang relavan dengan arus dinamika zaman yang senantiasa berubah.

4. Dari segi politik pengambilan kebijakan pendidikan Islam, untuk membantu mereka dalam membenahi sistem pengawasan dan mempertimbangkan kebijakan yang akan diterapkan dalam sistem pendidikan nasional (Islam).

${ }^{8}$ Rofa'ah, pentingnya Kompetensi Guru Dalam Kegiatan Pembelajaran Dalam Persfektif Islam, (Yogyakarta: CV Budi Utama, 2016), h. 25

${ }^{9}$ Ibid.

${ }^{10}$ Ahmad Izzan dan Saehudin, Hadis Pendidikan: Konsep Pendidikan Berbasis Hadis, (Bandung: Perpustakaan Nasional Katalog Dalam Terbitan), h. 214-215. 
Secara khusus, tujuan pelaksanaan evaluasi dalam pendidikan Islam adalah untuk mengetahui kadar kepemilikan dan pemahaman peserta didik terhadap materi pelajaran, baik dalam aspek kognitif, psikomotorik, maupun afektif. Kemudian tujuan evaluasi dalam pendidikan Islam adalah untuk menilai pendidik, yaitu sejauh mana ia telah bersungguh-sungguh dalam menjalankan tugasnya untuk mencapai tujuan pendidikan Islam. ${ }^{11}$

Semua fungsi atau kegunaan tersebut dimaksudkan untuk mengetahui kebaikan dan kelemahan pendidikan Islam dalam berbagai aspek dalam rangka peningkatan kualitasnya dimasa depan. ${ }^{12}$

\footnotetext{
${ }^{11}$ Suriyati, dkk., Ilmu Pendidikan Islam, (Sulawesi Selatan: CV Latinulu, 2019), h. 196.

${ }^{12}$ Ibid., h. 198.
} 


\section{BAB III \\ PENUTUP}

\section{A. Kesimpulan}

Metode adalah suatu cara yang tepat dan cepat dalam suatu cara yang efektif dan efisien untuk mencapai tujuan yang ditentukan. Banyak sekali metode yang dapat digunakan dalam penddidikan islam, asalkan dalam penerapan metode yang digunakan tersebut, tidak bertentangan dengan prinsip-prinsip ajaran Islam serta disesuaikan dengan materi pembelajaran pendidikan Islam yang sedang diberikan kepada peserta didik.

Tujuan pelaksanaan evaluasi dalam pendidikan Islam adalah untuk mengetahui kadar kepemilikan dan pemahaman peserta didik terhadap materi pelajaran, baik dalam aspek kognitif, psikomotorik, maupun afektif. Kemudian tujuan evaluasi dalam pendidikan Islam adalah untuk menilai pendidik, yaitu sejauh mana ia telah bersungguh-sungguh dalam menjalankan tugasnya untuk mencapai tujuan pendidikan Islam.

\section{B. Saran}

Setiap karya pasti mempunyai kelebihan dan juga kelemahan, saya selaku penulis merasa bahwa makalah yang telah dibuat ini masih banyak kekurangannya oleh karna itu penulis senantiasa mengharapkan saran dan kritik yang dapat membangun semangat penulis agar dapat membuat makalah yang lebih baik. 


\section{DAFTAR PUSTAKA}

Ahmad Izzan dan Saehudin, Hadis Pendidikan: Konsep Pendidikan Berbasis Hadis, Bandung: Perpustakaan Nasional Katalog Dalam Terbitan.

David Moeljadi, dkk., Kamus Besar Bahasa Indonesia Edisi Kelima, Jakarta:

Badan Pengembangan Bahasa Dan Perbukuan, 2016.

Halid Hanafi, dkk., Ilmu Pendidikan Islam, Yogyakarta: CV Budi Utama, 2018

Anggraini, D., Arbaini, W., \& Arsil, A. (2020). Model Pembelajaran Remi (Rajin,

Efektif, Menyenangkan Dan Imajinatif) Dalam Meningkatkan Kemampuan

Berfikir Kritis Siswa. Jurnal Al-Qalam: Jurnal Kajian Islam \& Pendidikan, 12(2), 14-27.

Irmayanti, I., \& Danial, D. (2019). Eksplorasi Etnomatematika Permainan Pada

Siswa Sekolah Dasar Di Sinjai Selatan. Auladuna: Jurnal Pendidikan

Dasar Islam, 6(1), 90-104.

Haryanti, Ilmu Pendidikan Islam, Malang: Penerbit Gunung Samudera, 2014.

Rofa'ah, pentingnya Kompetensi Guru Dalam Kegiatan Pembelajaran Dalam Persfektif Islam, Yogyakarta: CV Budi Utama, 2016.

Suriyati, dkk., Ilmu Pendidikan Islam, Sulawesi Selatan: CV Latinulu, 2019. 